\title{
The Color of Justice without Prejudice: Youth, Race, and Crime in the Case of the Harlem Six
}

\section{Carl Suddler}

In its time, the case of the Harlem Six captured national headlines, yet its significance escapes the public memory and record of many today. Ignited by the 1964 death of a white shopkeeper in Harlem, the case and its subsequent events resonated across the United States as black youth encounters with the carceral state influenced public discourse on youth, race, and crime. This article recovers the experiences of the Harlem Six to demonstrate how, by the 1960s, constructions of youth criminality were reestablished as a racial problem that required state intervention and punitive responses. As New York City officials authorized anticrime laws such as "stop-and-frisk" and "no-knock," which contributed to higher arrest rates in mainly black communities, it was the youths who bore the brunt of inordinate policing. For the Harlem Six, in particular, their narrative reveals the overwhelming power of the state and attests to the firmness of race as a crucial determinant in American notions of crime and delinquency.

"This is the hardest day of our lives," William Craig told reporters at a crowded news conference outside the New York State Supreme Court on April 4, 1973. Having spent nearly a decade in jail on a first-degree murder charge, Craig was one of the four Harlem Six youths released after pleading guilty to the lesser manslaughter charge; the other two continued to serve sentences. The court's promise of freedom forced the four young men to make the pragmatic decision rather than face the uncertainty of another trial for the 1964 murder 
of Margit Sugar, a white secondhand clothes dealer in Harlem. The three previous trials were complicated, and it became clear that nobody wanted to go through another trial that promised an uncertain verdict. In recognition of the overwhelming power of the state, the difficult decision was made to accept guilt for an offense in which they upheld their innocence. ${ }^{1}$

What started on a sunny April day in 1964, the case of the Harlem Six confirmed the persistence of race as a decisive factor in American notions of crime and delinquency. A sequence of events that spanned four decades, the intertwined stories of William Craig, Wallace Baker, Walter Thomas, Ronald Felder, Daniel Hamm, and Robert Rice - the latter two were released in 1974 and 1991 - expand our understanding of youth encounters with the carceral state in the second half of the twentieth century. Black youths account for a bulk of the young people who enter the justice system; however, their experiences continue to elude the broader historical narrative being shaped around the carceral state. Because the historical sources tend to be about youths, not from them, a great deal of the scholarship is rarely from their perspective. The combined archive accessed to retell the story of the Harlem Six allows us firsthand insight to how black youths, some criminalized by association, navigated the expansive justice system in the urban North. ${ }^{2}$

For all its particularities, the story of the Harlem Six points to a critical juncture in the carceral turn in the City That Never Sleeps. However, the experiences for black youths in New York City, as James Baldwin poignantly describes, was "true of every Northern city with a large Negro population" because in the "supposed bastion of liberalism," they contested the status quo for fair housing and public schools in addition to a better justice system. The case of the Harlem Six demonstrates that despite important moments of progress in the first half of the twentieth century, crime was recast as a racial problem that warranted punitive state responses, and efforts to create a fair and impartial justice system gave way to systemic and institutionalized racism. By the 1960s, anticrime laws, most notably stop-and-frisk and no-knock, were disproportionately being enforced in mainly black communities; the police were reaffirming their positions as the "frontline soldiers" for the impending War on Crime; and black youths continued to bear the burden of a justice system that denied their innocence and presumed their criminality. ${ }^{3}$

\section{"Harlem Is a Police State": Creating the Climate for Civil Unrest}

"The police in Harlem, their presence is like occupation forces, like an occupying army," Malcolm X told the audience at the Militant Labor Forum of New York on May 29, 1964. "They're not in Harlem to protect us; they're not in Harlem to look out for our welfare," he continued. "They're in Harlem to protect the interests of the businessmen who don't even live there." Having just returned from a trip abroad, Malcolm X's charges concerning the police state 
in Harlem reinforced many of the claims made by other Harlem residents and organizations. In 1964, the temper of central Harlem had grown sullen as its residents faced a surge in police presence directly connected to new anticrime laws and a "hate-gang scare" in the print media. Combined with the political buzz surrounding Harlem, this created an environment that sparked both major and minor incidents between the police and the community. ${ }^{4}$

The incident that sparked the case of the Harlem Six took place on April 17, 1964, when a fruit stand was overturned by black and Puerto Rican youths around 128th Street and Lenox Avenue. The documented reports of the "Harlem Fruit Riot" changed over time; however, the one constant that remained was when the police showed up to stop the youngsters from smacking each other with apples and oranges; the youths then "changed their targets, hurling fruit at the policemen." The policemen apprehended several of the youngsters and sent out a call for help to which roughly twenty-five more police responded. Several of the eyewitness accounts that detailed what ensued were disturbing. In a tape-recorded statement with a representative of Harlem Youth Opportunities Unlimited (HARYOU), Wallace Baker, nineteen, recalled seeing "some little boys picking up fruit from the ground" when three policemen "grab[bed] one between his legs and [got] ready to hit him with a stick." Baker continued, "So I ran over and tried to stop him. And two of them jumped on me and beat me for nothing." Baker was then put in the patrol car and handcuffed to Daniel Hamm, eighteen, who also intervened "to keep him [the policeman] from shooting the kids." For Baker and Hamm, this marked the beginning of a long struggle with the justice system. ${ }^{5}$

For many Harlem residents, the "policemen's inept handling of a minor situation" reinforced their skepticism of the heightened police presence in the community. "The black people of Harlem have come to understand the situation quite well," one writer wrote in Challenge, a weekly newspaper funded by the Harlem Progressive Labor Movement. "When the deal goes down, these cops will murder, maim, and brutalize the Negro people of New York just as fast as their partners in the south." For youth in particular, trepidation toward law enforcement existed for years; however, in this moment, the newly prepared stop-and-frisk and no-knock state laws roused a different antipolice sentiment - a feeling fueled with dishonesty and injustice. ${ }^{6}$

These two bills were proposed at a conference with New York Governor Nelson A. Rockefeller in January 1964, and the top law enforcement officials from New York City agreed on the terms "to reestablish law and order." The two bills, stop-and-frisk and no-knock, implemented particular proposals to combat crime, as they clarified the rights of police to frisk suspects and expanded the use of search warrants to be executed without notice to the occupants of a building. According to the 1964 Uniform Crime Reports, New York City was engulfed with street crime, reporting a 23 percent increase since the turn of the decade. "In an era in which crime is increasing four times as fast as the population" as said by Governor Rockefeller, these new laws were needed 
"because of the uncertainty in the present law and because the police must be provided now with the sound tools to carry out their sworn duty to protect the public against serious crimes." These anticrime bills were not passed without protest from liberal Republican and Democratic legislators, African American political organizations such as the National Association for the Advancement of Colored People (NAACP) and the Congress of Racial Equality (CORE), and resident New Yorkers from all parts of the city. Nor were they passed without countless victims, mostly youths of color who became familiarized with the criminal justice system for the first time. ${ }^{7}$

In the case of stop-and-frisk, it was reasoned, the uncertainty that existed around detainments caused tumult between citizens and police because policemen were rarely certain whether a detention was constitutionally valid. Police officials argued that the mandatory exclusionary rule of Mapp v. Ohio restricted effective police action. Prior to the 1961 Supreme Court decision, which declared evidence obtained in direct violation of the Fourth Amendment that prohibits unreasonable search and seizures could not be used in criminal prosecutions, half of the country's state courts, including New York, permitted incriminating evidence in state and federal courts regardless of how it was seized. Police officials demanded their state legislature pass a law that "would permit a policeman to detain and frisk a suspect on the grounds of reasonable suspicion, thereby eliminating the necessity of grounds for arrest." Thus, urged by law enforcement agencies including district attorneys, police chiefs, sheriffs, the state police, the State Commission of Investigation, and the State Council of Churches, New York enacted a stop-and-frisk statute. The bill was passed by a near-party-line vote of thirty-three to twenty-two - only one Democrat voted for it and only one Republican against it. ${ }^{8}$

There was less opposition to the "no-knock" bill that the Senate approved by a vote of forty-three to twelve. The "no-knock" law allowed policemen to break open a door or window without prior notice to the occupants of the building to execute a search warrant. The bill's proponents, who included Governor Rockefeller and New York City Mayor Robert F. Wagner, argued the necessity for such a law was twofold. One, the element of surprise did not allow the occupants time to destroy convictable evidence. "Such evidence as narcotics or policy slips are often thrown out of windows or flushed down toilets before police can seize it," New York Assemblyman Richard J. Bartlett imparted. The other aim of the bill was to protect police officers. According to Bartlett, "A policeman who knocks or announces that he is about to enter often gives the suspect enough warning to get out a gun or a knife." Although the stop-andfrisk law dominated the headlines, perhaps rightfully so, the combination of the two anticrime laws drastically transformed the relationship between police authority and the residents of New York, especially in Harlem. ${ }^{9}$

Opponents of the new anticrime laws in New York questioned their constitutionality and vagueness. Of the stop-and-frisk bill, a representative of the State Bar Association who argued for the bills to be vetoed said, "Nowhere, 
in the history of Anglo-Saxon jurisprudence have we so closely approached a police state as in this proposal to require citizens to identify themselves to police officers and 'explain their actions' on such a meager showing." Even the less opposed no-knock bill, according to the association, "flies in the face of a long-established policy that 'a man's home is his castle,' and for the state to invade it, it must strictly comply with safeguards which have been found to be important over the years." African Americans from the Harlem Progressive Labor Movement were more direct in their critique of the laws, describing them "as close to any of Hitler's laws as any other law in this country." But these concerns were met with a straightforward rebuttal: times have changed. ${ }^{10}$

The New York City Police Department, at least according to Police Commissioner Michael J. Murphy, had its hands full in 1964. Not only did these two laws impede the perception of police throughout the city, especially among communities of color, but it also added to the visibility of the police state being established. Fully aware that "police are confronted with serious problems in 1964; problems not encountered a few brief years ago," Commissioner Murphy negotiated complicated terrain. On the one hand, with the World's Fair set to embark on New York City, the police were responsible to preserve the peace and protection of the people. "As the threats and boasts of wild and unreasonable actions" loomed, the police commissioner showed an ardent stance on crime because he believed "the show of strength is the greatest deterrent to unlawful action." And as a result, more than 25,000 men were assigned to twelve-hour shifts throughout the city. ${ }^{11}$

On the other hand, the hordes of police brutality charges that the department confronted, including those stemming from the "Harlem Fruit Riot," suggest that the department's strength was not just a show. The national director of CORE, James Farmer, declared, "Police brutality in our city is not a problem which began or ended with the World's Fair." Farmer pointed to several instances in which excessive police force was utilized, and he concluded that there existed "an ongoing problem of police violence against individual Negroes and Puerto Rican unjustified and unprovoked." But according to Police Commissioner Murphy, his police force was being "subjected to unfair abuse and undeserved criticism" from those who sought "to destroy their effectiveness and to leave the city open to confusion." Contrary to what the CORE director penned in his statement, which captured the viewpoint of those throughout the streets of New York City, the police commissioner was adamant in saying, "There is no pattern of brutality in the New York City Police Department. There has not been-there will never be." 12

If in fact Police Commissioner Murphy's eradication of brutality allegations were true, the masses of black New Yorkers never received the memo. For those youngsters involved in the fruit stand fracas, in particular, the course of their lives was significantly altered by their interactions with the police on that day. Once the confrontation ended and several members of the crowd were taken away in patrol cars to the 135th Street station, unbeknownst to the authorities, 
about thirty youths followed and formed a picket line chanting, "Stop police brutality!" Outside of the police station, the marching and chanting lasted for three hours; inside, according to their recorded testimonies, the police brutality was just starting. "When they got us to the precinct station," Wallace Baker detailed, "they beat us practically all that day, and then at night they took us to Harlem Hospital to get X-rays." Daniel Hamm's experience was similar. "They beat us till I could barely walk and my back was in pain," Hamm described. "They got so tired beating us they just came in and start spitting on us." The police department denied all accusations. ${ }^{13}$

The evidence pertaining to the beatings these youths suffered proved otherwise. The mothers of both Baker and Hamm affirmed their sons' testimonies and contacted a black lawyer, George Sena, to defend their claims. In a tape-recorded statement with an interviewer from HARYOU, Mrs. Baker remembered going to the hospital "to sign for Wally because they thought they had broke his neck." "His neck was over one-sided," Mrs. Baker described. "He had a patch right across his lip, [and] his face was swollen." Daniel Hamm's mother was unaware of the disturbance that led to her son's arrest. "They didn't call me," Mrs. Hamm stated. But when she was finally permitted to see Daniel, she remembered, "He couldn't pull up his pants. He had a blood clot on each leg." Their attorney, Sena, used this evidence to plead their case for release. ${ }^{14}$

The next morning, Sena argued to the presiding judge, Maurice W. Grey, that his clients were "beaten by police after they had been arrested" for asking an officer "why he was beating another youth." The youngsters accompanied Sena in court, wearing bandages; however, Judge Grey dismissed the police brutality charge and told attorney Sena "to take his complaint to Police Commissioner Michael J. Murphy." The young men were forced to post $\$ 500$ bails, except Daniel Hamm, who was paroled in consideration of possible hardship to his widowed mother, and they were charged with assault and malicious mischief. Unfortunately for Baker and Hamm, they and four of their friends were rearrested within days of the fruit stand incident. This time, they were being charged with the murder of Margit Sugar, a white secondhand clothes dealer in Harlem. Such allegations bestowed on these six black youths incited racial and political disarray throughout New York City. ${ }^{15}$

\section{"They Don't Want Us on the Street": Policing Black Youths with Fear}

"The police were afraid of everything in Harlem," James Baldwin wrote in "A Report from Occupied Territory." "This means that the citizens of Harlem, who, as we have seen," Baldwin continued, "can come to grief at any hour in the streets, and who are not safe at their windows, are forbidden the very air." Baldwin's articulation of living in occupied territory poetically described what many black New Yorkers experienced in the mid-1960s, especially the youth. "The children, having seen the spectacular defeat of their fathers- 
having seen what happens to any bad nigger and, still more, what happens to the good ones - cannot listen to their fathers," Baldwin avowed, "and certainly will not listen to the society which is responsible for their orphaned condition." Moreover, speaking directly to the case of the Harlem Six and the passing of the stop-and-frisk and no-knock laws, Baldwin asserted that black people in New York City were no longer safe from the occupying forces of the state, not even in their own homes. "Harlem believes, and I certainly agree," he wrote, "that these laws are directed against Negroes." 16

People close to the case believed, like Baldwin, that the pursuit of these six youths started even before the fruit stand incident. Because of the new anticrime laws and the heightened police state in Harlem, certain actions and behaviors started attracting police attention and impacted youth perspectives of carceral authorities in the city, particularly the police. Some behaviors were tied to the elevated political climate in New York City and included rent strikes, school boycotts, spontaneous picketing, demonstrations, and the formation of militant rank and file. Others included innocent acts of adolescence, such as pigeon keeping. Many youths were pigeon fanciers, and they kept and trained pigeons on the roofs of residential buildings. One youth, not connected to the Six, explained to a New York Times reporter that he "hated" the police because "they took our pigeons." The youth told the reporter about a confrontation with a policeman who accused him and his friends of "hiding bricks" on the roof. All of the Harlem Six were pigeon fanciers, and though there was no record of their having run-ins with the police because of this hobby, they were all very aware of the youths who did. At an open forum in Harlem after the fruit stand riot, before his arrest, Hamm pointed to the constant harassment from police and expressed, "They don't want us on the street"-a message they all heard loud and clear. ${ }^{17}$

The New York Times printed the first detailed account on the murder of Margit Sugar under the headline "3 Youths Seized in Harlem Killing: A Racial Motive in Recent Assaults Is Investigated." The writer goes into detail about three "Negro youths" who were arrested in connection with the fatal stabbing of a Harlem shopkeeper and the wounding of her husband, Frank Sugar, who was in fair condition at Physicians' Hospital in Jackson Heights in Queens. Frank Sugar told police that a group of boys entered the store just before 5:00 p.m. and took up position around the shop. He recounted, "When one of the youths asked to see a suit, Mrs. [Margit] Sugar replied that they had none in his size." Another youth then drew a knife and stabbed the woman once in the heart. The commotion in the store caused the operator of the adjacent drugstore to come over and see what was going on. The drugstore operator, Julius Levitt, described seeing a group of youths run out of the clothing store, and he called the police. The following morning, Ronald Felder, Walter Thomas, and William Craig were arrested and arraigned on charges of felonious assault and a violation of the weapons law; the homicide charge was held open until it could be determined which "boy did the killing." 18 
Coverage of the assault continued the next day in the New York Times when they printed a photograph of young Robert Rice and Daniel Hamm attached to an article connecting the youths to the death of Margit Sugar. "Altogether, five teen-agers have been arrested in the shopkeeper's murder," longtime New York Times reporter Martin Arnold stated, "and a sixth [was] being sought." The police issued an alarm that spanned a thirteen-state radius in their efforts to capture the sixth, Wallace Baker, who was believed to have "actually stabbed Mrs. Sugar to death." As a result, the hunt for Baker received national attention; however, on May 5, Baker, accompanied by his lawyer, George Sena, turned himself in. With the Six officially in police custody, perhaps the most important question yet to be answered was, Why were six Black youths all arrested, indicted, and arraigned for a murder that the police say "was committed by one stroke of a knife in a human heart by one bloody hand." Why so many? ${ }^{19}$

A multiple accusation of such hostility can fix an ugly stain on a whole race or nationality. Otherwise, it would just be a random act of violence. There were the Scottsboro Seven and the Trenton Six. "Whenever a crescendo of racist fear and guilt begins to build in the white community," according to the novelist Truman Nelson, who published a great deal in support of the Harlem Six, "it seems that it must always be resolved by a frenzied hue and cry, brutal arrests, and hysterical trial of multiple black defendants accused of a crime so monstrous that the whole apparatus of the state backed by a totally terrorized and convinced public opinion can be brought into a direct onslaught against them." This was indeed true in the case of the Harlem Six. ${ }^{20}$

From the onset of their arrest through all the events that followed, the Harlem Six experienced harsh treatment by the various authoritative figuresthe police, their lawyers, the courts - they encountered, reinforcing their notions about the unjust powers of the state. Aside from Wallace Baker, who turned himself in to police custody, the other five youths and their families faced noknock enforcement in their arrests. "On the night of April the twenty-ninth," two months before the stop-and-frisk and no-knock laws were set to become official, Mrs. Craig, William's mother, recalled hearing a noise coming from the roof. She opened her door to look out and saw roughly twenty men, some coming up the stairs and some down from the roof. "One walked to the door and he asked me if this was where Billy Craig lived," Mrs. Craig recollected. "I said Billy Craig? No, there's no Billy Craig here. There's a Willie Craig live here." But William was out running an errand. This did not prevent the policemen to go in to Craig's room, and four of the men stayed in the house to wait for Craig's arrival. "The others left, and I'd say about forty-five minutes later," Mrs. Craig stated, "one come up the stairs and say we got him." William's mother followed the police officers back to the precinct, where she waited hours for any questions to be answered. Mrs. Craig left the police station per a detective's request to "go home and get some rest so you can be in court in the morning, 'cause we are keeping these boys." "I didn't know why they were holding them no more than just as assault," Mrs. Craig explained. "I couldn't 
think of anywhere I could go for help. I felt everything was hopeless." When she arrived back home, Mrs. Craig's daughter and neighbor told her that they saw the "three boys on television" and that they were arrested for murder. ${ }^{21}$

Each of the six mothers, including Wallace Baker's mother, shared similar stories of the day their sons were arrested and faced death sentences. Mrs. Rice, Robert's mother, was said to have weighed 152 pounds before her son's arrest and dropped to 125 pounds within a month. "I haven't been able to eat a meal since all this started. All I do is smoke and drink coffee," Mrs. Rice told Selma Sparks, a feature writer for Challenge who interviewed the six mothers to reveal "what it feels like to be a black mother in a white world when your child is being framed and tortured." Sparks's interviews were published in a pamphlet titled "A Harlem Mother's Nightmare: The Story of Six Harlem Youths Who Face Possible Death for a Crime They Did Not Commit." Committed to raise awareness and money to help defend the Harlem Six, the Committee to Defend Resistance to Ghetto Life (CERGE), a New York-based defense front organization for the Progressive Labor Movement and its affiliates, promoted the pamphlet and launched a national, arguably international, campaign to free the Harlem Six, and their mothers led the charge..$^{22}$

It was Truman Nelson's The Torture of Mothers, a self-published account of the mothers' experiences and the early media coverage on the case of the Harlem Six, that established the national conversation and "create[d] publicity and public indignation." Nelson, a white northerner, held little qualms in what he knew to be "a racial incident." "If six Irishmen kill a Jew, if six Jews kill a Pole, if six Poles kill a Negro, if six Negroes kill a white," Nelson expressed, "the guilt is flung in the face of a whole people." In the case of the Harlem Six, Nelson indeed believed this to be true. The work was not without its skeptics, however. An unlabeled letter mailed to Beacon Press, which eventually decided to publish the work in late 1965 "with the hope that the book will now attract the concern which it deserves," described Nelson's work as "frank propaganda." The unnamed writer professed that the book only "succeeds in demonstrating to a white reader how far removed he is from the kind of justice, the kind of law, and the police the Negro knows." This was certainly true; however, in his time of writing, Nelson never proclaimed to do more than expose the injustices the six youths and their families faced. He built his case around the Harlem Six mothers and their "excruciating torture, which comes out of love." "It comes out of uncertainty and fear," Nelson wrote, "out of wanting to protect, in this case, and not being able to find the object of the compulsion to protect." Such a tone set the tone for the first trial, which began in March 1965- ten months after their arrests. ${ }^{23}$

\section{"They Are All Your Children": Freeing the Harlem Six}

"No one in Harlem," James Baldwin wrote, "will ever believe the Harlem Six are guilty—God knows their guilt has certainly not been proved." Baldwin 
voiced what many Black New Yorkers, especially Harlemites, felt about the six youths who faced the death penalty for a felonious murder charge. "Harlem knows, though, that they have been abused and . . possibly destroyed, and Harlem knows why - we have lived with it since our eyes opened on the world." Yet the worst ordeal of the mothers was still to come. The six mothers formed the Mother Defense Committee "in an effort to free their children." Such a feat proved to be a daunting challenge they were prepared to accept. ${ }^{24}$

Although countless Harlem residents wanted to trust that the Six were in fact innocent, not many were forthcoming in their defense. "Everybody turned their back on us and gave us the run-around," Walter Thomas's mother remembered. Mrs. Hamm supported this claim, testifying that a representative of the NAACP told her that "they wouldn't touch the case with a ten-foot pole." Even George Sena, who represented the youths after the fruit stand debacle, denied the role to defend the Six in their case against the death of Margit Sugar. It was generally believed, at least according to Truman Nelson, that "somehow the press had been able to implant in them a new form of original sin." Counter to their advocates, the media portrayal of the Harlem Six was able to convince many members of the community "that they were killers because they were black." ${ }^{25}$

A significant portion of the media connected the murder of Margit Sugar to "four other Harlem murders, all of white persons," and associated the Harlem Six to an antiwhite Harlem gang indoctrinated by rebel Black Muslims. Junius Griffin, an African American reporter for the New York Times, broke the story on the "Blood Brothers" of Harlem and reported that the gang had upward of 400 members. Griffin, who claimed to have received the information on the youth gang from a HARYOU researcher, implicated the Harlem Six, particularly Wallace Baker and Daniel Hamm, in his front-page story, stating, "The gang last clashed with the police on April 17 on the east side of Lenox Avenue. ... Two members of the gang were arrested in that clash and were later implicated in the fatal stabbing of a white woman on April 29."26

The presence of a Harlem gang "indoctrinated in hatred of all white persons" was quarrelsome for everyone. A day after the New York Times printed its initial report of the antiwhite Harlem gang, it published a detailed account of how the police were addressing the problem. To investigate the gang's existence, Griffin reported, "more than 40 Negro police undercover men moved into Harlem yesterday." They fanned out into community centers, restaurants, bars, and "other haunts where members of the gang [were] reported to gather during and after school hours." When challenged to present evidence, however, Griffin and the New York Times denied all requests. ${ }^{27}$

There were some African American organization leaders who, unsure if the gang existed, admitted it would not be surprising if such a group did. For example, James Farmer, the national director of CORE, wrote, "I think the Blood Brothers are merely another indication of the sickness of our society. They reflect the growing anger, frustration and sense of hopelessness in the 
Negro ghetto, especially among our youth, most of whom are unemployed." Be that as it may, black media outlets were not as willing to accept the existence of the "Blood Brothers" and warned its audience of the possibilities that may arise if they accept what has emerged elsewhere. The New York branches of the NAACP and CORE demanded that "the city to produce the facts to justify the hysteria that has been created." Whether the intentions were to better the business opportunities for non-Harlem residents to feel more comfortable moving to Harlem or to permit the establishment of the heightened police presence, Marshall England, chairman of the New York CORE, articulated that reports were "an indication of how far the white press will go to create hysteria." In the end, the gang's existence eluded all evidence presented; however, the damage was done..$^{28}$

In their initial hearings, largely because of Griffin's reports, the Harlem Six faced questions such as, "Are you a follower of Islam?," "How do you get your X?," and "Where do you fellows practice your karate?" The assistant district attorney, Robert J. Lehner, even asked Daniel Hamm directly, "When Rice [Robert] called you brother, what does he mean?" To which Hamm responded, "Just something new that come in the street. Instead of pal it's brother." The implication in these questions was directly tied to the idea that the Six belonged to the "Blood Brother" gang that was never proved to be more than a myth. The hysteria, unfortunately, was not. ${ }^{29}$

Because of the hysteria, though, many lawyers believed providing a credible defense was going to be extremely difficult, even if they knew the "Blood Brother" connection was untrue. Those close to the case of the Harlem Six labored to find an attorney to conduct their defense. As a result, after their arraignment, one lawyer signed a notice of appearance for all the youths. This meant that when any other lawyer, whether chosen by their mothers or not, asked for permission to see the boys, he or she would be denied. The mothers believed that the lawyer who signed the notice of appearance did so for the money; the court-appointed lawyer was "paid $\$ 2,500$ per boy." Like most people in Harlem, the mothers and their sons both had a deep distrust of courtappointed counsel, and they refused to settle. ${ }^{30}$

The Mothers Defense Committee was determined to obtain a defense counsel they were confident in; however, as Mrs. Baker acknowledged, "We didn't know where to go, we didn't know where to turn." Their next option was William Epton, a black communist who at the time was the head of the Harlem Defense Council. An ardent opponent of the no-knock and stop-andfrisk laws, what he referred to as "the northern version of the Black Codes," Epton was hesitant to take on the case out of fear that "Rockefeller, Wagner, and 'Bull' Murphy" would use his radicalism against him. Even though Epton denounced his affiliation with the Communist Party in 1964 "because it no longer represented the aspirations in general of the working class or the black people in particular," the stigma was still prevalent. ${ }^{31}$ 
Epton suggested that the Mothers Defense Committee talk their situation over with Conrad Lynn, a civil rights attorney who had recently defended Epton on a charge of illegal assembly. Known for his "oratorical power ... openness, compassion, and above all ... innate sense of righteousness and prophecy that was the hallmark of the great abolitionists of the 1850s," Lynn seemed to be the perfect fit. Truman Nelson, a Lynn supporter and friend, described the attorney as "a small man, and black, and his smallness and blackness gives the effusions of indestructibility and fearlessness." Nelson admitted it was easy for him "to understand how the mothers must have felt sitting before him for the first time." Lynn agreed and assembled a group of distinguished attorneys that included Mary Kaufman, William Kunstler, Sam Neuberger, and Gene Condon. He accepted the case because he believed "the so-called Blood Brother murder is one pre-eminently showing the influence of dominant prejudice against a minority which is deprived of defenses." Lynn also informed the mothers of the Six that actual hard proof of the crime by the boys is missing, and "the prosecution is depending on the existing state of prejudice to obtain conviction." Placing his faith in the mothers' testimony, Lynn was convinced the boys were innocent and accepted the task at hand. ${ }^{32}$

The first step for Lynn and his team proved to be the first hurdle. Sought to represent the Harlem Six, Lynn stated, "My colleagues and I have surveyed every scrap of the alleged 'evidence,' and, without a doubt, we believe these six black youths to be innocent." But because there was already a court-appointed attorney, the court invoked a ruling that denied Lynn's group the defense. Not surprised by the judge's decision to keep the assigned attorney, Lynn expressed his dissatisfaction with "the judge [who] would refuse to appoint any lawyer except the particular political hack in the Democratic Club whom they wished to favor at the moment." Lynn's group immediately motioned to the Supreme Court for a writ of habeas corpus to free the Harlem Six on the grounds that they were being denied the right to counsel. He argued, "The practice of the courts in assigning lawyers against the wishes of indigent clients was to practice a difference in defense based on property qualifications." Confident that the precedent set in the Scottsboro case to use the class status of the defendants would persuade the judge to reconsider, Lynn and his team were once again denied. Judge Julius Helfand, who adjudicated the habeas corpus hearing, was unwilling to fold on the class distinction. Judge Helfand was more convinced by the attorney general's argument: "If you let these people pick their own lawyer, pretty soon the indigents in the hospitals will be picking their own doctors and surgeons." Judge Helfand dismissed the plea of the six youths and ordered them to go on trial for their lives. ${ }^{33}$

A retrial for the Six was crucial for many reasons. First, and perhaps most important, the boys were no longer subjected to the attorneys appointed by the court. For Lynn and his associates, attaining a fair environment for this case was a fight they refused to drop. In one instance, the lawyers demanded that Supreme Court Justice Gerald P. Culkin "be censured for his racial slurs." When 
the Six appeared before Culkin to attempt to change their counsel, Culkin said, "These boys wouldn't know a good attorney from a good watermelon." Fritz Alexander, president of the Harlem Lawyer Association, expressed to Lynn and his team that the association "found no racial offense in the statement Culkin made." On a separate occasion, according to Lynn and William Kunstler, one court-appointed lawyer "died in court from acute alcoholism while the first trial was in progress." These kinds of occurrences marred the first trial throughout, but the retrial would now allow Lynn and his associates to take over the case on a more permanent and official basis. ${ }^{34}$

Second, from the time the Six were convicted in 1964 to the order for a retrial, the death penalty underwent a number of changes in New York. In 1965 , state legislation passed a law limiting the death penalty "to murder in the first degree when the victim was a peace officer performing his or her official duties, when the defendant was serving a life sentence at the time the crime was committed, if the crime was committed when the defendant was serving an indeterminate sentence of at least fifteen years to life, or if the defendant was in immediate flight from penal custody or confinement when the crime was committed." Further, the law prohibited the death penalty for persons under the age of eighteen when the crime was committed and did not impose the death penalty "when substantial mitigating circumstances existed." Some more amendments were added in 1967 and 1968, though what mattered most was the Harlem Six would no longer be facing the electric chair-only life in prison. And, finally, the order for a retrial meant the six youths-Rice, Hamm, Baker, Felder, Craig, and Thomas - were to now be tried separately. The New York Court of Appeals said, "When a defendant confesses to a crime, he must be given his own trial apart from the trials of his co-defendants." In this particular instance, because Rice and Hamm "confessed" to knifing the Sugars, each was set to face a jury of his peers individually; a joint trial was set for Wallace, Thomas, Felder, and Craig, who "stoutly maintained their innocence." 35

After the Court of Appeals reversal, there was a new emergence of support for the Harlem Six. Because Rice and Hamm were tried and sentenced separately, the public started to follow the "Harlem Four" case closely. Following three mistrials, all of which resulted in hung juries, relatives and supporters demanded the removal of the assistant district attorney, Robert Lehner, who had prosecuted the case for more than seven years. Ossie Davis, a well-known black actor and activist, called the case "an outrage," and he called for the Harlem Four, "who have been denied bail since their arrest seven years ago," to be released immediately and renounced of all charges. Various petitions supported this call, including one signed by countless psychiatrists, psychologists, social workers, and psychoanalysts who believed another trial "would impose unbearable psychological stress on these young men." 36

The charges were not recanted, and a fourth trial was set for the Harlem Four. This trial, according to Lynn and his group, was "expected to last about a month," and the new jury was going to "hear most of the same witnesses 
who testified at previous trials." While this remained pretty standard, à la the first three mistrials, there were some new additions that made this trial seem different. The New York Times assigned a new reporter to the case, Lacey Fosburgh, whose first article on the Harlem Six reintroduced the case to a new audience of readers who may have lost track over the course of seven years. Perhaps most notably in Fosburgh's report, all connections to an "anti-white hate gang" were absent, and the case was presented as "six teen-agers [who were a part of] an unholy plot to kill proprietors." Fosburgh also made an effort to humanize the defendants. There was mention of Walter Thomas's nine-yearold daughter, who spent most of her young life with her father in jail, as well as William Craig's poems that were exhibited in the Countee Cullen Library in Harlem. ${ }^{37}$

In addition to the new reporter, there was also a new audience-one that included young boys and young girls who saw themselves in the defendants. "I can't help thinking that could be me," Vaughan Dweck, thirteen, told a New York Times reporter. "I'd be scared if I was up there like that. All those years waiting and wondering was going to happen to you," Dweck continued. "I'd be scared and I'd be real glad to see someone like me sitting here watching." Dweck was one of more than 100 youths who regularly attended the trial that was opened to the public at the Criminal Court Building. Richard M. Edelman, an eighthgrade social studies teacher from the Fieldston School, was just one of many teachers who believed that "the unusual elements in this case - its long history, the fact that it focuses on a murder and, particularly, the defendants' youthcombine to intrigue the students." Edelman, whose students were assigned to write reflection paragraphs after their day in the courtroom, quickly learned that "the essays revealed the realization that the four boys had been held in jail without bail during a crucial period in their life was confusing and troublesome." Even some younger relatives of the Harlem Six were writing letters and being engaged. For example, Cheryl Samuels, thirteen-year-old cousin of Ronald Felder, wrote a letter to the Harlem Six disclosing her experience. "When I was ten I'd hear a cousin of mine was in jail but I didn't know what for," Samuels wrote. "Now that I'm 13 I can really do a little something to help. Pass out leaflets in court that a girl in my class made and a lot of other things that real help get the news around." Lynn and William Kunstler, who by this point in the trial had taken a more prominent role in the defense, welcomed the youths who showed up because they believed that "interest among the young in the legal system should be encouraged." It also boosted their defense. ${ }^{38}$

After the three-month trial and days of jury deliberations, the jurors found themselves "hopelessly deadlocked," and Supreme Court Justice Joseph A. Martinis issued another mistrial-except for the first time, Thomas, Felder, Craig, and Baker were set to be released on bail. But, as Lewis M. Steel, a member of the defense team put it, "How can poor black people raise $\$ 75,000$ ?" The sum total to be paid, Steel argued, was so high as to amount to no bail at all. "I expected after eight years they would be released in their own recognizance." 
But Justice Martinis felt he was doing the boys a favor "in all good conscience." Bail was not posted. ${ }^{39}$

Satisfied with the defendants' inability to pay the fee, the assistant district attorney characterized the Harlem Four as "much too dangerous to be granted bail." William Craig responded directly to Lehner in the courtroom. "Then indict me for it!" The judge warned Craig to be quiet, and Craig declined. "I've been sitting here quiet for too long," he voiced, "through damned near four trials, and I'm not going to keep quiet as long as you keep talking about this justice business." Craig's vented frustration vocalized an undercurrent of distrust, which many black youths shared, in the justice system. One trip through his poem exhibit at the Countee Cullen Library would have anticipated Craig's outpouring. In a poem titled "Power," he wrote, "After seven and a half years of being promised justice and fairness, We, the 'Harlem 6,' as well as any poor black person, have received injustice and partialness." No longer able to believe in the courts, Craig declared, "The residing judge promises justice, but the moment his mouth opens there's a great contradition [sic] and all motions are denied under the color of justice without prejudice." Conrad Lynn concurred. "I'm much more bitter about life and what's happened to them than they are," Lynn wrote, having worked the trial since its inception. "They're angry naturally about what's gone on these eight years, but they've developed a philosophy of life that's much more serene than I'll ever have." In that moment, the decision was to be made by Justice Martinis, who had two options: declare a retrial or dismiss the original indictment altogether. ${ }^{40}$

Justice Martinis's self-designated March 8 deadline came, and all signs pointed to a fifth trial for the four defendants. That was until, perhaps the most significant turning point in the case, the key prosecution witness, Robert Barnes Jr., confessed to his probation officer that "his testimony [against the Harlem Six] was a lie." Aside from the testimony of "two small girls who testified that they had seen the defendants near the murder scene," the prosecution's case rested largely with Barnes, who the prosecution described as an original coconspirator in the murder plan. For the defense, this new information was a gold mine. Lynn's group argued that if Barnes did not participate in the murder case, "it then becomes obvious the police and other public officials involved most certainly engaged in the wilful [sic] subornation of perjury." In the event that this holds true, it would be argued that the prosecution changed the character of Barnes's participation in the crimes "to exculpate him and implicate these defendants therein." The defense called for an immediate release of the four defendants and a thorough criminal investigation of the new findings. Whether or not Justice Martinis was impacted by this information, it did lead to a number of immediate changes, including the reduction of the bail fee, which was posted, and the four defendants were released from the Manhattan House of Detention on March 31, 1972. ${ }^{41}$

The "freedom" of the Harlem Four was short lived, and by the summer of 1972, they were summoned for another trial. Lynn and Kunstler worried 


\section{Carl Suddler}

about another trial because they believed the choice language of the justice was "deliberately designed to inflame and prejudice the future jurors." They were, however, prepared to report the progress their defendants made in the few months of freedom: Felder was accepted into City College of New York and was scheduled to attend in September, Craig was enrolled at Harlem Prep, Thomas was working as a legal aide at the Morrisania Legal Services Clinic, and Baker was actively participating in community work. Justice Martinis acknowledged their "commendable" progress but called for another retrial because he believed the defense sympathizers "violated the general principles of decency and 'subjected' both himself and the jurors to 'unfair pressures.", But the defense was ready and believed that Barnes's admission to lying, which was submitted in a thirty-eight-page affidavit, gave them what was needed to finally end this case. And it $\operatorname{did}^{42}$

Then, on April 4, 1973, almost nine years to the day and just days before the retrial was scheduled to begin, the Harlem Four were finally freed after pleading guilty to manslaughter charges. The decision was complicated, as the four (now men) proclaimed their innocence. "We've said all along we are not guilty and what we feel the world should know is that we are still not guilty," Craig told reporters at a news conference. "We hope our friends, our mothers, our fathers, anybody who cares will understand why we had to do this, why we had to make this decision." For the Harlem Four, the certainty of freedom, even at the price of a criminal record, was the better option than facing the uncertainty of another trial. Later, Supreme Court Justice Jacob Grumet, who took the place of Martinis, made "a highly unusual move" to grant the four a certificate of relief from disability. "I want[ed] them to have every chance," Justice Grument explained, defending his decision to assure that the Harlem Four would not lose any rights or privileges commonly stripped of convicted felons. For all intents and purposes, William Craig, Wallace Baker, Walter Thomas, and Ronald Felder were free. ${ }^{43}$

The fates of Daniel Hamm and Robert Rice were yet to be determined. For Lynn and his defense team, their focus shifted on procuring the same freedoms as their other Harlem Six comrades. Hamm, who continued to serve his sentence at Auburn prison in upstate New York for his guilty plea, was denied his first parole opportunity "on the basis of new information." The Charter Group for a Pledge of Conscience, a small community organization composed of mainly Harlem residents, printed "An Appeal to the Community" on behalf of Hamm, and they urged, "ANY MEMBER OF THE COMMUNITY WHO KNOWS ANYTHING ABOUT THIS ALLEGED 'CONFIDENTIAL INFORMATION'-PLEASE COME FORWARD SO THAT IT CAN BE PUBLICLY EXAMINED." As a result of a combination of the group's effort and the persistence of Lynn and his associates, Hamm was released in 1974. ${ }^{44}$

Rice, who the defense team figured would be released after a federal judge dismissed his murder conviction in September 1973, experienced the least good fortune. He went on to face five additional trials and seven appeals with no 
break. His mother continued her advocacy and used the New York Amsterdam News as an outlet for support. Mrs. Rice wrote "An Appeal to the Harlem Community for Help to Free My Son, Robert Rice," which was printed in the distinguished black newspaper, urging New York Governor Hugh Carey to grant her son clemency. Having spent twelve years in prison, Rice was "the only one of the Harlem Six still behind bars." Unfortunately, because of the bloc of Mrs. Rice's plea and the tireless effort of Lynn and his defense team, clemency was not granted. Rice continued to serve his sentence; he went up for parole in March 1988, and he was finally released in November 1991. ${ }^{45}$

"Your concern for the children brought about a change in your life," Craig wrote in a note to Wallace Baker. "You, Wallace, was caught in the middle of hells front door, while I tried hard to fight my way to your side," he recounted of the fruit stand melee, "But the ocean of blue uniforms stoped [sic] me in my tracks." Even years after, Craig admittedly remembers every detail "because the effects of those blows changed both our lives." As black youths growing up in postwar Harlem, the odds were already stacked against them. In a note to Conrad Lynn, Truman Nelson affirmed, "They know the struggle will not end with them, or perhaps even their grandsons, but they have made a contribution with the dignity and strength with which they have fought the good fight." But such affirmation was embedded. "I'm well aware that it's not justice. And I'm sure it's not equality," William Craig wrote the state of the justice system in America. "But through it all the 'Harlem 6' will maintain strength to fight the struggle against racism, fascism, oppression, injustice, and exploitation." ${ }^{46}$

In its time, the case of the Harlem Six captured national headlines and international audiences, yet its significance continues to escape the memory and record of many. The case, ignited by the 1964 death of a white shopkeeper in New York City, and its subsequent events were emblematic of black youth experiences with the carceral state as the nation embarked on its War on Crime. The lived experiences of these six youths reveal that by the 1960s, constructions of criminality were reestablished as a racial problem that would continue to face more punitive state responses influenced by broader discourse on youth, race, and crime. The Harlem Six persevered through a justice system that, long before them, decided to attribute race as the determining factor for those presumed innocent and those presumed criminal.

\section{Notes}

1. William Craig was quoted in various newspaper reports of four of the Harlem Six being released after pleading guilty to the lesser manslaughter charges. See "'Hardest Day of Our Lives": Harlem Four," New York Times, April 8, 1973, 239, and "Harlem 4 Freed after 9 Years," AfroAmerican, April 14, 1973, 21.

2. Scholars have chosen the term "carceral"- "of or belonging to prison"- to invoke a wide range of punitive state action. For a sampling of recent historical journal articles and monographs on the modern American carceral state, see Kelly Lytle Hernández, Khalil Gibran Muhammad, and Heather Ann Thompson, eds., "Special Issue: Historians and the Carceral State," Journal of American History XX (June 2015): 18-184; Heather Ann Thompson and Donna Murch, eds., "Special Section: Urban America and the Carceral State," Journal of Urban History XX (September 2015): 751-861; Naomi Murakawa, The First Civil Right: How Liberals Built Prison 


\section{Carl Suddler}

America (New York: XXXX, 2014); Dan Berger, Captive Nation: Black Prison Organizing in the Civil Rights Era (Chapel Hill: University of North Carolina Press, 2014); Elizabeth Hinton, From the War on Poverty to the War on Crime: The Making of Mass Incarceration in America (Cambridge: XXXX, 2016); and James Forman Jr., Locking Up Our Own: Crime and Punishment in Black America (New York: Farrar, Straus and Giroux, 2017). On the lack of youth experiences in the historical records, historian George Lipsitz writes that "public records most often reflect the concerns of those in power and only rarely contain evidence of the thoughts, action, or aspirations of teenagers and young adults unless those groups are seen as some kind of threat to people with power." See George Lipsitz, "Who'll Stop the Rain? Youth Culture, Rock 'n' Roll, and Social Crisis," in The Sixties: From Memory to History, ed. David Farber (Chapel Hill: University of North Carolina Press, 1994), esp. 206-34. For a more recent take on the methodological difficulties facing historians of youth, see Joseph M. Hawes and N. Ray Hiner, "Hidden in Plain View: The History of Children (and Childhood) in the Twenty-First Century," Journal of the History of Childhood and Youth XX (Winter 2008): pp. 43-49. More recently, historians of African American girlhood have paved the way to better incorporate youth experiences from the margins to the centers of historical studies. See Roundtable by Corinne T. Field, Tammy-Charelle Owens, Marcia Chatelain, Lakisha Simmons, Abosede George, and Rhian Keyse, "The History of Black Girlhood: Recent Innovations and Future Directions," Journal of the History of Childhood and Youth 9, no. 3 (Fall 2016): 383401.

3. For Baldwin's description of Harlem, see James Baldwin, "A Report from Occupied Territory," The Nation, July 11, 1966, 6. Historians Brian Purnell and Jeanne Theoharis referred to New York City as the "capital of the Jim Crow North." See Brian Purnell and Jeanne Theoharis, "How New York City Became the Capital of the Jim Crow North," Washington Post, August 23, 2017, http://www.washingtonpost.com (accessed November 26, 2017). For a sample of the postwar historiography that emphasizes the limits of racial liberalism in the urban North to demystify the narrative of the North as a utopian melting pot, see Jeanne Theoharis and Komozi Woodard, eds., Freedom North: Black Freedom Struggles outside the South, 1940 to 1980 (New York: Palgrave Macmillan, 2003). For a more specific example of how black youths fought for equal access to housing and schooling in the urban North outside of New York City, see Andrew Diamond, Mean Streets: Chicago Youths and the Everyday Struggle for Empowerment in the Multiracial City, 1908-1969 (Berkeley: University of California Press, 2009). On police as the "frontline soldier," see Lyndon B. Johnson, "Statement by the President Following the Signing of Law Enforcement Assistance Bills," September 22, 1965 (online by Gerhard Peters and John T. Woolley, The American Presidency Project, http://www.presidency.ucsb.edu [accessed November 1, 2017]).

4. Malcolm X referred to Harlem as "a police state" in his speech at the Militant Labor Forum of New York on May 29, 1964. See Malcolm X, Malcolm X Speaks: Selected Speeches and Statements, ed. George Brietman (New York: Merit Publishers, 1965), esp. 64-71.

5. The first print media report of the "Harlem Fruit Riot" was published in the New York Times on April 18, 1964. The headline described the incident as "75 in Harlem Throw Fruit at Policemen." The following day, two days after the incident, the New York Times carried a slightly different version. It was written as "four youths and a man, were involved in a free-for-all on Friday afternoon, after they allegedly overturned a fruit stand." The difference is important because the "four youths and [the] man," who the proprietor of the fruit stand told the police were not at his store, would go on to face the charges. See "75 in Harlem Throw Fruit at Policemen," New York Times, April 18, 1964, 27, and "Lawyer for 5 Tells Court Police Roughed Up Clients," New York Times, April 19, 1964. Willie Jones from HARYOU conducted the tape-recorded statements of Wallace Baker and Daniel Hamm. They are cited in Truman Nelson's The Long Hot Summer (Berlin: XXXX, 1967), 129 n. 4, 129 n. 6.

6. On "the policemen's inept handling of a minor situation," see Junius Griffin, "Harlem: The Tension Underneath; Youths Study Karate, Police Keep Watch and People Worry; Harlem; Tension Close to Surface as Summer Tests Approach; Youngsters Take Karate Training; Peaceful Residents Worry as a Police Concentrate Key Forces in Area," New York Times, May 29, 1964, 13. See also "Harlem Unite: Let Us Defend Ourselves!," Challenge: The New Revolutionary Weekly Paper, n.d., Box 4, Folder 17D, Conrad Lynn Collection, Howard Gotlieb Archival Research Center, Boston University.

7. Douglas Dales, "2 Bills Prepared on Police Search: Law Enforcement Aides in State Reach Agreement," New York Times, January 21, 1964, 18. On opponents of the two anticrime bills, see Martin Arnold, "N.A.A.C.P. and CORE to Fight Bills Increasing Police Powers," New York Times, February 29, 1964, 24, and Douglas Dales, "Rockefeller Signs Bills Increasing Powers of Police: Bar and Civil Rights Groups Call 'Stop-and-Frisk' and 'No-Knock' Laws Illegal,' New York Times, March 4, 1964, 1. I think it is important to note that although these two laws had become a subject of national concern in the mid-1960s, the police power to detain and question is "as old as the common law of England." For a long history of stop-and-frisk that was referenced in the 1960s, see Loren G. Stern, "Stop and Frisk: An Historical Answer to a Modern Problem," Journal of Criminal Law, Criminology, and Police Science 58, no. 4 (1967), esp. 532. 
8. Mapp v. Ohio, 367 U.S. 643 (1961). For a more comprehensive history of Mapp v. Ohio, see Carolyn N. Long, Mapp v. Ohio: Guarding against Unreasonable Searches and Seizures (Lawrence: University Press of Kansas, 2006). On police demands for a stop-and-frisk statute, see Memorandum of the New York State Combined Council of Law Enforcement Officials to the New York State Legislature in Relation to Temporary Questioning and Search for Weapons, cited in "The 'No-Knock' and 'Stop and Frisk' Provisions of the New York Code of Criminal Procedure," St. John's Law Review 38, no. 2 (May 1964), esp. 393. As written, the stop-and-frisk statute allowed policemen "to stop any person abroad in a public place whom he reasonably suspects is committing, has committed or is about to commit a felony or a serious misdemeanor." Further, if the policeman "reasonably suspects that he is in danger of life or limb from the person he has stopped, he may search the person for a dangerous weapon." And if he finds a weapon or "any other thing, the possession of which may constitute a crime, he may keep it during the questioning." Thereafter, he must either return the item it was lawfully possessed or arrest the person for possessing it. On the "stop-and-frisk" statute of 1964, see N.Y. Code Crim. Pro. § 180-a (effective July 1, 1964). The stop-and-frisk statute in New York was derived from the Uniform Arrest Act of 1942, which gave police officers the right to arrest any person who they reasonably believed was committing or had committed a felony or misdemeanor. For more on the Uniform Arrest Act of 1942, see "The Uniform Arrest Act," Virginia Law Review 28, no. 3 (January 1942): 317. On the vote breakdown, see Layhmond Robinson, "Legislators Pass Anticrime Bills: Senate Sends Rockefeller His 'Stopand-Frisk' and 'No-Knock' Measures," New York Times, February 19, 1964, 41.

9. On the "no-knock" statute of 1964, see N.Y. Code Crim. Pro. § 799 (effective July 1, 1964). For a more detailed description of the two anticrime laws, see "The 'No-Knock' and 'Stop and Frisk' Provisions of the New York Code of Criminal Procedure," 392-405. On the proponents of "no-knock" and the vote breakdown, see Layhmond Robinson, "Assembly Votes Anticrime Bills: Measures Would Ease Laws on Searches by Police," New York Times, February 12, 1964, 41, and "Frisk-Law Advice Is Given to Police: City Warns against Hasty Use of New Powers," New York Times, June 28, 1964, 28.

10. Layhmond Robinson, "Bar Group Urges Crime-Bills Veto: Sees Threat of 'Police State' in Additional Powers," New York Times, February 12, 1964, 39. On the Harlem Progressive Labor Movement's description of the two laws, see "Harlem Unite: We Have Come to Understand," Challenge, n.d., Box 4, Folder 17D, Conrad Lynn Collection, Howard Gotlieb Archival Research Center, Boston University.

11. Michael J. Murphy, Civil Rights and Police: A Compilation of Speeches by Michael J. Murphy, New York City Police Department (New York: XXXX, 1964), pp. 11, 9, emphasis in the original. For an example of how print media portrayed the strength of the police force surrounding the World's Fair, see Theodore M. Jones, "Murphy Alerts Police for Fair: Emergency Duty to Cope with Stall-In Threat and Opening Events Police Put on Emergency Duty to Prepare for the Opening of the Fair," New York Times, April 18, 1964, 1, 16.

12. On James Farmer's statement, see Richard J. H. Johnston, "Murphy Charges Attack on Police: Says 'Brutality Complaints Seek to Weaken Force," New York Times, April 29, 1964, 28. On Police Commissioner Murphy's stance against the brutality allegations, see Murphy, Civil Rights and the Police, 12, 13, emphasis in the original.

13. On the roughly thirty youths marching and chanting, see "75 in Harlem Throw Fruit at Policemen," 27. Tape-recorded statement of Wallace Baker, transcribed in The Long Hot Summer, 20. Tape-recorded statement of Daniel Hamm, transcribed in The Long Hot Summer, 23-25.

14. Tape-recorded statement of Mrs. Baker, transcribed in The Long Hot Summer, 21-22. Tape-recorded statement of Mrs. Hamm, transcribed in The Long Hot Summer, 25-27.

15. "Lawyer for 5 Tells Court Police Roughed Up Clients," New York Times, April 19, 1964, 47; "Cops Probe Brutality Cry in Wake of Fray," New York Amsterdam News, April 25, 1964, 55.

16. Baldwin, "Report from Occupied Territory," 5-6.

17. On the youth account of pigeon keeping in Harlem, see Junius Griffin, "View in a Harlem Street: 'Whitey' Won't Give Me a Job; Teen-Agers Express Futility by Asking: Why Go to School?," New York Times, May 9, 1964, 13. In James Baldwin's "Report from Occupied Territory," he too makes mention of pigeon fanciers who "kept pigeons on the roofs" and argues that police were "especially afraid of the roofs, which they considered to be guerilla outposts"; see Baldwin, "A Report for Occupied Territory," 5. On Daniel Hamm's description of police harassment after the fruit stand incident, see Truman Nelson, The Torture of Mothers (Boston: XXXX, 1965), 63.

18. On the New York Times's first detailed account of the incident, see "3 Youths Seized in Harlem Killing: A Racial Motive in Recent Assaults is Investigated," New York Times, May 1, 1964, 31 .

19. On the arrest of Rice and Hamm, see Martin Arnold, " 2 Held in Killing Admit Another; Will be Questioned on 2 More," New York Times, May 2, 1964, 55. On Baker's prearrangement, see "Suspect Gives Up in Harlem Death; New Youth Is 3rd Accused in Shopkeeper's Murder," New York Times, May 5, 1964, 32. For media coverage on the search for Baker outside of New York, see "Seek Negro, 19, Believed to Be in Racist Gang," Chicago Tribune, May 4, 1964, 3; "Police 


\section{Carl Suddler}

Claim Muslim Youth in Terror Gang," Chicago Daily Defender, May 6, 1964, 6; and "Young Racist Slaying Suspect in Custody," Atlanta Daily World, May 10, 1964, A1.

20. For a comprehensive history of the Scottsboro case, see Dan T. Carter, Scottsboro: A Tragedy of the American South (Baton Rouge: Louisiana State University Press, 1969; revised, 2007). For a comprehensive history on the Trenton Six, see Cathy D. Knepper, Jersey Justice: The Story of the Trenton Six (New Brunswick, NJ: Rutgers University Press, 2007). Truman Nelson published two separate books in support of the Harlem Six. The first, The Torture of Mothers, was a detailed account of the media coverage and firsthand interviews with witnesses and the mothers of the six youths. His second book, The Long Hot Summer, was written in the autumn of 1964 and describes "without later revision" events and conditions of the long, hot summer. It included various transcriptions of interviews with the Harlem Six and their mothers. For the Nelson quote, see Nelson, The Torture of Mothers, 43, and The Long Hot Summer (Berlin: XXXX, 1967), 52.

21. Tape-recorded statement of Mrs. Craig, transcribed in The Long Hot Summer, 39-42. The stop-and-frisk and no-knock laws were set to be enforced beginning in July 1964. For a more thorough account of the police precinct actions, including transcripts, see Charter Group, "Fact Sheet in the Case of 'the Harlem Six," esp. 1-9, Box 4, Folder 17D, Conrad Lynn Collection, Howard Gotlieb Archival Research Center, Boston University.

22. Selma Sparks, "A Harlem Mother's Nightmare: The Story of Six Harlem Youths Who Face Possible Death for a Crime They Did Not Commit" (cover matter, ca. 1965), CERGE, 1, 5.

23. On the case of the Harlem Six as a racial incident, see Nelson, The Torture of Mothers, 1, emphasis in the original, 45. On the letter mailed to Beacon Press, see "[No name] Letter," n.d., Box 4, Folder 17D, Conrad Lynn Collection, Howard Gotlieb Archival Research Center, Boston University. On the torture of mothers, see Nelson, The Long Hot Summer, 35-36.

24. James Baldwin, The Price of the Ticket: Collected Nonfiction, 1948-1985 (New York: XXXX, 1985), 424. On the mothers forming their own defense committee, see Harlem Defense Counsel, "Police Terror in Harlem," CERGE Political Pamphlet (1965), 4.

25. Tape-recorded statement of Mrs. Thomas, transcribed in The Long Hot Summer, 57. Tape-recorded statement of Mrs. Hamm, transcribed in The Long Hot Summer, 57. For Nelson's take on why the community became skeptical, see Nelson, The Long Hot Summer, 57-58.

26. The HARYOU researcher was never identified. Junius Griffin, "Anti-White Harlem Gang Reported to Number 400: Social Workers Says Its Members Are Trained in Crime and Fighting by Defectors from Black Muslims," New York Times, May 6, 1964, 1, 30.

27. According to Griffin's report, the New York Police Department reported leads on two adults, Orlando $\mathrm{X}$ and Hannibal, whom they suspected to be responsible for organizing and teaching the youth referred to as the Blood Brothers. Junius Griffin, "40 Negro Detectives Investigate AntiWhite Gang: U.S. Agency Studying Harlem-Civil Rights Groups Criticize Violence," New York Times, May 7, 1964, 28. Dr. Kenneth B. Clark, director of HARYOU, publicly stated, "There is nothing in the data collected by the HARYOU research staff which would support the contention that there exists in the Harlem community a group or groups of young people who are dedicated to organized anti-white violence. . . . and no such statement was made by a HARYOU staff member." See Les Matthews and George Barner, "They Still Can't Prove That 'Blood Gang' Lie!," New York Amsterdam News, May 23, 1964, 1, 55. Conrad Lynn, a civil rights attorney, demanded Griffin to present the evidence, to which he wrote, "He hasn't appeared. I am still waiting. He is afraid to face me after what he has done"; see Nelson, The Long Hot Summer, 67.

28. Griffin used many reports of organization leaders who made the case for the gang's existence. This also included Alexander J. Allen, the executive director of the Urban League of Greater New York, who wrote, "If it is true, upon reflection, it's an outcome of the long-standing alienation and rejection which Negro youths in Harlem and Bedford-Stuyvesant have faced for a long, long time - all their lives, in fact." See Griffin, "40 Negro Detectives Investigate AntiWhite Gang," 28. On black newspaper accounts that refuted the gang's existence and warned of its allegations, see Matthews and Barner, "They Still Can't Prove That 'Blood Gang' Lie!," 1, 55.

29. Statement of Wallace Baker, Made to Robert J. Lehner, ADA, May 4, 1964, transcript, esp. 3753-54, Box 4, Folder 17C, Conrad Lynn Collection, Howard Gotlieb Archival Research Center, Boston University. Statement of Daniel Hamm, Made to Robert J. Lehner, ADA, May 1, 1964, transcript, esp. 5, Box 3, Folder 17A, Conrad Lynn Collection, Howard Gotlieb Archival Research Center, Boston University.

30. Nelson tape, transcribed in The Torture of Mothers, 70.

31. Harlem Defense Counsel, "Police Terror in Harlem," CERGE Political Pamphlet (1965), 4; Nelson, The Torture of Mothers, 76; Les Matthews, "A Closeup of William Epton," New York Amsterdam News, August 15, 1964, 46.

32. Nelson, The Torture of Mothers, 77-78.

33. On Lynn's belief of the Harlem Six's innocence, see Sparks, "A Harlem Mother's Nightmare," 5. The 1901 ruling cited was People v. Fuller, which states, "A destitute defendant, charged with murder in the first degree, can have no part in selecting the counsel authorized to be assigned to him by the Court and paid for by the County." See The People of the State of New York, Plaintiff v. John Fuller, Court of General Sessions of Peace in and for the County of New York, 
May 1901, 35 Misc. 189 (N.Y. Misc. 1901). In the case of the Scottsboro trial, the defendants had court-appointed lawyers, but the Supreme Court ruled that Sam Liebowitz, a top criminal lawyer, could defend them and that they were not to be burdened legally with the errors they claimed were made by their court-appointed counsel. On Lynn's property as income defense, Lynn's transcribed statements appeared in Nelson's The Torture of Mothers, 79, 81-83, 85. According to various CERGE reports, the average African American family earned \$3,480 a year compared to the citywide average of $\$ 5,103$ yet were charged $\$ 50$ to $\$ 74$ a month for a one-room flat that would rent for $\$ 30$ to $\$ 49$ in a white neighborhood.

34. "Harlem Lawyers Back Judge," New York Amsterdam News, March 1, 1969, 42. On Judge Culkin's racial connotations, see Sidney E. Zion, "Judge Accused of Racial Slur against 'Harlem 6,"' Box 3, Folder 17A, Conrad Lynn Collection, Howard Gotlieb Archival Research Center, Boston University. See also Michael Newton, "Harlem Six," The Encyclopedia of American Law Enforcement (New York: XXXX, 2007), 150.

35. Joseph Lentol, Helene Weinstein, and Jeffrion Aubry, "The Death Penalty in New York: A Report on Five Public Hearings on the Death Penalty in New York Conducted by the Assembly Standing Committee on Codes, Judiciary, and Correction, December 15, 2004-February 11, 2005," 12; N.Y. Sess. Laws 1965, chap. 321. In 1967, the death penalty was amended to include intentional murder, depraved indifference to human life, murder, and felony murder; see N.Y. Sess. Laws 1967, chap. 791. In 1968, the act of recklessly engaging in conduct evincing a depraved indifference to human life that results in the killing of another was removed from the list of death eligible crimes; see N.Y. Sess. Laws 1968, chap. 949. Lesley Oelsner, "One of 'Harlem 6' Guilty in Retrial: Other 5 to Be Tried in 1964 Murder of Shopkeeper," New York Times, April 11, 1970, 27.

36. Robert Rice explained to the jury that he "confessed only after being beaten by the police." He was charged guilty of first-degree murder, attempted murder, and attempted robberythe murder conviction alone carried a mandatory sentence of life imprisonment. Daniel Hamm pleaded guilty to manslaughter, attempted murder, and robbery; he was sentenced to fifteen to thirty-five years. On the Rice and Hamm confessions, see Letter from Conrad J. Lynn to Hon. John V. Lindsay, Mayor, New York City, January 31, 1972, Box 3, Folder 17B, Conrad Lynn Collection, Howard Gotlieb Archival Research Center, Boston University. The same letter was sent to Shirley Chisholm, congresswoman, and Hon. Percy Sutton, Manhattan borough president. On the first three mistrials, see Lesley Oelsner, "One of 'Harlem 6' Guilty in Retrial: Other 5 to Be Tried in 1964 Murder of Shopkeeper," New York Times, April 11, 1970, 27; "Harlem Six Face Sugar Murder," New York Amsterdam News, April 18, 1970, 2; “Awaiting Jury Verdict," New York Amsterdam News, March 20, 1971, 1; "Harlem Six Retrial in Hung Jury," New York Amsterdam News, March 27, 1971, 1; and Charlayne Hunter, “3d Trial Begins for 'Harlem Six': Defenders' Backers Demand Removal of Prosecutor," New York Times, September 22, 1971, 28. For the Ossie Davis quote, see Hunter, "3d Trial Begins for "Harlem Six," 28. The untitled, signed petition is in Box 3, Folder 17B, Conrad Lynn Collection, Howard Gotlieb Archival Research Center, Boston University.

37. Lacey Fosburgh, "4th Trials Opens for 4 Accused of ' 64 Store Murder in Harlem," New York Times, November 30, 1971, 50.

38. Lacey Fosburgh, "Trial Here of the 'Harlem Six' Interests Student Observers of All Age Groups," New York Times, January 9, 1972, 62; Letter from Cheryl Sanders to "Yo' Brothers," March 19, 1972, Box 4, Folder 17C, Conrad Lynn Collection, Howard Gotlieb Archival Research Center, Boston University.

39. On the juror deliberations, see Lacey Fosburgh, "Defense in Harlem Slaying Trial Rests after Calling One Witness," New York Times, January 18, 1972, 63. On the decision to offer bail after a fourth mistrial, see Lacey Fosburgh, "Case of the 'Harlem 4' Ends in Hung Jury: Case of 'Harlem 4' End in a Hung Jury for a 2d Time,’ New York Times, January 28, 1972, 1, 19.

40. On Craig's outburst in the courtroom, see Fosburgh, "Case of the 'Harlem 4' Ends in Hung Jury," 19. William Craig, "Power," poem, Box 3, Folder 17B, Conrad Lynn Collection, Howard Gotlieb Archival Research Center, Boston University. On Lynn's concurrence, see Lacy Fosburgh, "Harlem 4: When Is Justice Done?," New York Times, February 20, 1972, E10. On Justice Martinis's decision, see "Harlem Four to Get Word on March 8," New York Amsterdam News, February 19, 1972, A3.

41. "Harlem 4 Postponed," New York Amsterdam News, March 11, 1972, A2; Philip C. Cooper, "The Harlem Six: Justice on Trial," New York Amsterdam News, March 18, 1972, A5; Lacey Fosburgh, "Case against 'Harlem 4' Said to Be Based on Lie," New York Times, March 18, 1972, 1, 35; Lacey Fosburgh, "Conflict Is Denied in Harlem 4 Data: New Disclosure Backs Its View, Prosecution Says," New York Times, March 23, 1972, 37; Lacey Fosburgh, “'Harlem 4' Due to Be Released Tomorrow as Bail Is Reduced to \$5,000 Each," New York Times, March 30, 1972, 28.

42. Lacey Fosburgh, "Witness Recants in Harlem 4 Case: Asserts Those He Identified Are Innocent, and Reports Intimidation by Police," New York Times, July 7, 1972, 1, 35, and "Harlem Four Facing Their Fourth Trial," New York Amsterdam News, July 8, 1972, C10; Lee Cook, "Harlem 4 Dismissal is Now 'A Must,"” New York Amsterdam News, July 29, 1972, C10. 


\section{Carl Suddler}

43. Lacey Fosburgh, “'Harlem Four' Are Freed after Manslaughter Pleas,” New York Times, April 5, 1973, 1, 55; "Harlem Four: 'Hardest Day of Our Lives," New York Times, April 8, 1973, 239; "Harlem 4 Freed!," New York Amsterdam News, April 7, 1973, A1. For national coverage of the Harlem Four being released, see "Free 4 in Plea Switch," Chicago Defender, April 5, 1973, 7, and "High Court Denies Delay for Retrial of Black Youths," Jet Magazine, April 12, 1973, 29. Lewis Steel, of Lynn's defense team, suggested that the prosecution was more amenable to a plea now because another trial might be political embarrassing for the incumbent district attorney.

44. Fosburgh, “'Harlem Four' Are Freed after Manslaughter Pleas,” 55; James M. Markham,

"Parole Is Granted but Then Revoked for a 'Harlem Six' Inmate: Packing to Leave Conviction Voided," New York Times, March 6, 1973, 45; newspaper insert, New York Amsterdam News, March 9, 1974, A11, emphasis in the original; William Worthy, "Last of 'Harlem Six' Inmates Victim of 'Compromise' Solution,” Baltimore Afro-American, November 6, 1979, 5.

45. "Robert Rice, Harlem Six, Awaits Bail," New York Amsterdam News, August 11, 1973; "Murder Charge Dismissed against One of Harlem Six," New York Times, September 15, 1973, 35; United States Rice v. Vincent, 491 F.2d 1326; Arnold H. Lubasch, "Ruling to Throw Out Conviction in 'Harlem Six' Case Reversed," New York Times, February 8, 1974, 38; "State High Court Upholds a 'Harlem Six' Conviction," New York Times, October 10, 1974, 57; newspaper insert, New York Amsterdam News, June 5, 1976, A10, emphasis in the original; H. Carl McCall, a New York Amsterdam News journalist, published an article, "A Perversion of Rehabilitation," in support of Robert Rice's release. He wrote, "The voice of Harlem has spoken in the past concerning the Harlem Six case. That same voice must be heard again, and now louder and more persistently than ever before." H. Carl McCall, "A Perversion of Rehabilitation," New York Amsterdam News, June 12, 1976, A5; Worthy, "Last of 'Harlem Six' Inmates Victim of 'Compromise' Solution," 5. For the most recent status update on Robert Rice, see Department of Corrections and Community Supervision, New York State, "Inmate Information," http://nysdoccslookup.doccs.ny.gov/ GCA00P00/WIQ3/WINQ130.

46. William Craig to Wallace Baker, "To Wallace Baker," letter, Box 3, Folder 17B; Truman Nelson to Conrad Lynn, n.d., Box 3, Folder 17A; and William Craig, "Power," Box 3, Folder 17B (all Conrad Lynn Collection, Howard Gotlieb Archival Research Center, Boston University). 